\title{
Uma homenagem ao tricentenário de Rousseau
}

Professor livre-docente da Faculdade de Educação d

Sílvio Gallo

Américo Grisotto

Professor Adjunto do Depto. de Filosofia da Universidade Estadual de Londrina

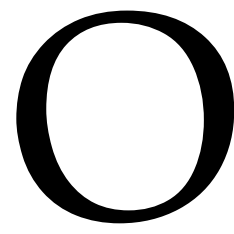

ano de 2012 marca o tricentenário do filósofo genebrino Jean-Jacques Rousseau (1712-1778). Mas a efeméride é dupla, pois marca também os 250 anos de publicação de duas de suas obras mais significativas: Do Contrato Social e Emílio, ou Da Educação, tendo ambas aparecido em 1762, ano em que o autor completou seus cinquenta anos.

Para uma revista dedicada a publicar textos nas confluências dos campos da Filosofia e da Educação, essa dupla efeméride não poderia deixar de ser lembrada, com uma homenagem ao polêmico filósofo. Nesta edição publicamos o dossiê Rousseau, composto por 10 textos inéditos que abordam a obra do filósofo em diferentes perspectivas e em diversos aspectos, mas com nítido acento nas temáticas educacionais.

E não é para menos. Emílio, ou Da Educação, nasceu polêmico. Rompendo com o Estado, que o autor considerava corrupto e corruptor, mas rompendo também com a Igreja, em nome de uma "religiosidade natural", a obra foi condenada pelas duas instituições. Queimada em praça pública em Paris e em Genebra, a obra foi renegada e seu autor perseguido, tendo que exilar-se para não cair na 
prisão. Mas, ao mesmo tempo em que nasceu polêmica, esta é, certamente, uma das obras fundadores da educação moderna, exercendo suas influências até nossos dias.

Nada mais apropriado para homenagear um filósofo do que fazer com que suas ideias permaneçam vivas, instigando o pensamento. O conjunto de artigos que publicamos nesse dossiê cumpre esse papel.

Abrimos com o artigo de Fernando Bonadia de Oliveira, $O$ Emílio de Rousseau: uma obra de pedagogia?, no qual o autor problematiza essa obra fundadora. Estudada muitas vezes no âmbito da história da educação, ou então no campo da filosofia, Oliveira defende e argumenta que ela pode e deve ser lida como obra de pedagogia, na medida em que impactou e segue causando impacto na pedagogia moderna.

Em seguida, temos o texto de Vilmar Alves Pereira, A educação como ponto de confluência na obra de Jean-Jacques Rousseau. Procurando encontrar o papel da educação em três obras do filósofo e pedagogo Jean Jacques Rousseau, Emílio, Do contrato social e Emile e Sophie ou Os solitários, o autor não apenas identifica a grande coerência presente no pensamento desse autor a respeito da educação, em projeto no Emílio, como sustenta a tese de que não existe contradição entre aquilo que Rousseau pensou como educação e o que entende por política. A propósito, na proposta que Rousseau apresenta nas três obras analisadas, a educação funciona como importante ponto de 
confluência, o que faz com que o autor ofereça elementos bem interessantes e intricados (como a presença da sociedade civil), os quais permitem observar tanto as implicações educacionais do pensamento de Rousseau quanto um objetivo mais amplo que, ao alicerçando-se no Emílio, estende-se politicamente pela obra Emile e Sophie ou Os solitários (pouco frequentada pelos especialistas) e desemboca nos conceitos de vontade geral e liberdade, em Do Contrato Social.

Em Diretrizes da educação na primeira infância segundo JeanJacques Rousseau, Arlei de Espindola explora os aspectos mais importantes que Rousseau desenvolve nos dois primeiros livros do Emílio, que tratam do desenvolvimento da criança na primeira infância, notadamente voltada para o desenvolvimento físico e a exploração dos sentidos.

Sobre esse tema, igualmente, debruçam-se Maurício Rebelo Martins e Claudio A. Dalbosco em Rousseau e a primeira infância. Analisando e avaliando as considerações que o filósofo genebrino faz no livro I do Emílio, os autores destacam a importante mediação do adulto no processo em que a criança tomará consciência de sua dependência social e sua autonomia, bem como a ideia de que devemos respeitar a natureza da criança tendo em vista as especificidades advindas do seu mundo. Entre a presença do adulto no mundo da criança e o que seria a autonomia dessa última, colocase um problema: como manter a mediação do adulto, com seus 
valores, de modo a não contaminar o mundo da criança? Eis a trama que os autores tentam desembaraçar.

No artigo seguinte, Devaneio e Educação, Vagner da Silva explora um tema polêmico, que encontrará pontos de vista diversos neste mesmo dossiê, ao afirmar não ser a questão pedagógica o cerne da obra de Rousseau. Embora afirme que ela constitui um todo coerente, o autor tampouco defende que a antropologia e a política sejam esse ponto agregador. Para ele, o devaneio, como elemento cíclico da obra de Rousseau, é que, paradoxalmente, dá-lhe coerência.

Uma preocupação de Rousseau que não aparece de forma explícita diz respeito a uma educação pública; neste dossiê, ela é abordada pelo texto de José Benedito Almeida Júnior, A educação pública em Rousseau. A proposta de uma educação pública, marcada pela máxima de uma "desnaturação", é confrontada com a perspectiva de uma educação doméstica, centrada no lema de "seguir a natureza". $\mathrm{O}$ artigo dedica-se a explorar esse paradoxo.

No artigo Por uma pedagogia da tolerância, Israel Alexandria Costa e Tereza Cavalcante Albuquerque exploram, analisando o tratado de educação de Rousseau, a noção de "piedade natural", perguntando se ela poderia ser vista como um engajamento do filósofo na luta contra a intolerância, ao modo de um de seus principais críticos, Voltaire. 
O tema do cuidado da infância reaparece, mas sob outro enfoque, no artigo de Pedro Angelo Pagni, Das virtualidades do cuidado da infância em Rousseau ao seu pleno governo na arte pedagógica. Agora, trata-se de vislumbrar tanto em Rousseau como em Kant as virtualidades mencionados no título, contrapondo-as ao extenso domínio que se exerce sobre a infância nos dias atuais. Descortinando as práticas da arte pedagógica contemporânea, o autor preocupa-se em pensar Rousseau, hoje, na contramão dessa pedagogia instituída que governa a infância.

Fechamos o dossiê com um presente aos leitores. Américo Grisotto, um dos organizadores, traduziu as notas de aula preparadas por Gilles Deleuze para um curso sobre a filosofia política de Rousseau, levado a cabo na Sorbonne durante o ano acadêmico de 1959-1960. Essas notas, encontradas datilografadas nos arquivos da universidade, estão disponíveis, em Francês, no site que reúne textos e documentos de Deleuze. Aparecem aqui pela primeira vez em Português, em tradução realizada especialmente para esta edição. Antepomos às notas de Deleuze um artigo em que o tradutor as comenta, situando-as no contexto do presente dossiê-homenagem.

O presente número de Filosofia e Educação conta ainda com dois artigos, que tratam de outros temas.

O ensino de Filosofia, assunto de nosso número anterior, é revisitado por Karen Giovana Videla da Cunha Naidon, em Sentidos e possibilidades da aula de filosofia no ensino médio. A autora 
problematiza o trabalho com a disciplina Filosofia nesse nível de ensino, defendendo que ele esteja orientado para um exercício do filosofar, a partir de processos desenvolvidos por diferentes filósofos. Por fim, em Poderia a ciência cognitiva ser dividida entre natural e cultural?, Daniel Luporini Faria aborda um campo ainda não muito comum nesta revista, o da filosofia da mente. Partindo de uma análise crítica do livro Da ciência cognitiva à dialética, de Marcos Barbosa de Oliveira, o autor dialoga com autores como Popper e Dennett, analisando as transformações cognitivas.

Com este amplo leque de artigos, explorando mais detidamente a obra de Rousseau, assim como remetendo para além dela, Filosofia e Educação acredita oferecer aos leitores provocações bastante profícuas para o exercício do pensamento. Só podemos desejar: boa leitura! 